\title{
PENERAPAN METODE EOQ DALAM PENGENDALIAN PERSEDIAAN BARANG PADA PT. CAKRAINDO MITRA INTERNASIONAL
}

\author{
${ }^{1}$ Deden Darusalam, ${ }^{2}$ Sugiyono* \\ ${ }^{1,2}$ Teknik Informatika Sekolah Tinggi Ilmu Komputer Cipta Karya Informatika \\ Jln. Raden Inten II No.8A, Duren Sawit, Jakarta Timur - DKI Jakarta, Indonesia \\ *e-mail1 : darusalamdeden61@gmail.com
}

Received: 2021-08-25, Revised: 2021-08-28, Accepted: 2021-09-02

Abstrak

Beranjak penelitian ini yaitu sebuah permasalahan yang ditemui pada PT. Cakraindo Mitra Internasional yaitu dalam divisi gudang dimana pengarsipan masih manual, peneliti melihat permasalahan tersebut mengajukan ide penelitian untuk diterapkan dengan metode EOQ ( Economy Order Quantity) Berdasarkan literature yang suda dibaca dari referensi-referensi yang sesuai dengan tema penelitian yang akan dijalani. Setelah mendapatkan literatur yang diperlukan, lalu peneliti dapat menentukan variable yang akan diteliti. Setelah menentukan variable yang akan diteliti, peneliti mengumpulkan data dari PT. Cakraindo Mitra Internasional untuk diolah dan diterapkan dengan metode EOQ ( Economy Order Quantity) yang hasilnya akan diimplementasipak pada pembuatan sistem berbasis web yang akan membantu pengguna untuk mengetahui interval barang yang sering dilakukan transaksi oleh pelanggan dalam setahun terakhir. Dengan telah dibuatnya web tersebut maka pengguna dalam hal ini yaitu PT. Cakraindo Mitra dapat mengetahui pelanggan yang sering bertransaksi dengan perusahaan dan barang yang dipesan selama setiap transaksi berjumlah berapa intervalnya dalam setahun.

Kata kunci: persediaan, Economy Order Quantity(EOQ), WEB

\section{Abstract}

Moving on to this research is a problem encountered at PT. Cakraindo Mitra Internasional, namely in the warehouse division where filing is still manual, the researcher sees the problem, proposes a research idea to be applied with the EOQ (Economy Order Quantity) method. After obtaining the necessary literature, the researcher can determine the variables to be studied. After determining the variables to be studied, the researchers collected data from PT. Cakraindo Mitra Internasional to be processed and applied with the EOQ (Economy Order Quantity) method, the results of which will be implemented in the creation of a web-based system that will help users to find out the interval of goods that are frequently transacted by customers in the last year. With the web has been made, the user in this case, namely PT. Cakraindo Mitra can find out which customers often transact with the company and the goods ordered during each transaction are at what intervals in a year.

Keywords: inventory, Economy Order Quantity(EOQ), WEB

\section{PENDAHULUAN (Introduction)}

Penggunaan teknlogi informasi yang berkembang seperti sekarang ini dapat dimanfaatkan dengan sebaik mungkin seperti diproses jual beli ataupun bisnis. Dalam proses bisnis, teknologi informasi dapat diaplikasikan dengan berbagai cara sesuai kebutuhan perusahaan tersebut. Umumnya perusahaan yang memanfaatkan teknologi informasi dengan baik yaitu perusahaan yang sedang mengembangkan bisnisnya demi kepuasan pelanggan yang dikelolanya selama ini. Penggunaan teknologi informasi dapat digunakan untuk mengatasi masalah-masalah yang terjadi 
dalam perusahaan tersebut seperti masalah pendataan barang-barang yang dikelolanya untuk diposes kepenjualan.

Namun, tak sedikit perusahaan belum memanfaatkan teknologi informasi dengan baik. Dengan arti lain masih banyaknya masalah-masalah yang muncul akibatnya kurangnya pengaplikasian teknologi informasi. Banyak perusahaan yang sedang mengembangkan eksistensinya dibidang bisnis yang masih kesulitan mempergunakan teknologi informasi salah satunya perusahaan dibidang bisnis yaitu PT. CAKRAINDO MITRA INTERNASIONAL. Pada perusahaan ini masih banyak bermunculan masalah seperti plus minusnya barang dalam pendataan penyediaan barangnya. Proses yang manual banyak sekali permasalahan yang disebabkan oleh human error.

Perlu adanya inovasi yang dapat membantu dan mempermudah aktifitas kerja sehari-hari dengan efektif. Dengan demikian peneliti tergugah untuk mengangkat permasalahan ini sebagai penelitian yang akan diterapkan pada PT. Cakraindo Mitra Internasional khususnya dalam proses persediaan barang yang sangat dibutuhkannya inovasi yang memudahkan pencatatan dan pemberkasan yang sangat aman dan meminimalisir terjadinya human error.

Berdasarkan permasalahan diatas, peneliti mengajukan tema tersebut untuk dijadikan judul pada penelitian ini yaitu "Penerapan Metode EOQ Dalam Pengendalian Persediaan Barang Pada PT. Cakraindo Mitra Internasional". Peneliti akan mengimplementasikan sistem ini pada proses persediaan barang dengan menggunakan metode EOQ yang merupakan metode persediaan barang yang menentukan jumlah pemesanan atau pembelian yang harus dilakukan dan berapa banyak jumlah yang harus dipesan agar dapat mengefesiensi biaya pemesanan dan biaya penyimpanan.

\section{TINJAUAN LITERATUR (Literature Review)}

Pada penelitian ini, peneliti merujuk dari beberapa referensi terdahulu yang akan menjadi gambaran referensi dalam membuat dan meneliti penelitian ini. Berikut referensi penelitian yang peneliti rujuk:

Penelitian yang pertama yaitu Penelitian Azmi Fahma dari Universitas Brawijaya Malang yang berjudul "Analisis metode EOQ sebagai dasar pengendalian persediaan bahan baku pembantu pada PG. Ngadirejo Kediri - PT. Perkebunan Nusantara X dengan bertujuan untuk mengetahui pengendalian persediaan bahan baku pembantu PG." Ngadirejo Kediri dan mengetahui pengendalian persediaan bahan baku pembantu dengan menggunakan metode Economic Order Quantity, dengan menggunakan jenis penelitian deskriptif dengan pendekatan kuantitatif. Sumber data dalam penelitian ini menggunakan sumber data sekunder yang diperoleh langsung dari perusahaan. Pengumpulan data menggunakan wawancara dan dokumentasi. Analisis data yang digunakan dalam penelitian ini adalah menggunakan metode Economic Order Quantity. Hasil dari analisis membuktikan bahwa apabila perusahaan menerapkan metode Economic Order Quantity pada tahun 2013, 2014, dan 2015 didalam pembelian bahan baku pembantu yang optimal. Berdasarkan hasil analisis yang dilakukan, maka sebaiknya PG. Ngadirejo Kediri menerapkan metode Economic Order Quantity didalam menentukan kuantitas pembelian bahan baku pembantu yang optimal, sehingga dapat meminimalkan total biaya yang dikeluarkan oleh perusahaan setiap tahunnya[1].

Penelitian selanjutnya yaitu penelitian dari Bambang dengan judul "Rancang Bangun Aplikasi Penjualan Dan Persediaan Obat Pada Apotek Merben oleh Yuntari Purba Sari Program Studi Sistem Informasi STMIK Prabumulih Apotek Merben bergerak dalam penjualan obat resep maupun non resep." Dari Obat generic sampai obat tradisional. Apotek ini sudah berdiri dari tahun 2013 sampai dengan sekarang. Apotek Merben masih menggunakan sistem manual dalam penjualannya maupu pengelolaan data obatnya. Sistem manual itu adalah dengan menggunakan Alat Tulis Kantor (ATK) dalam penjualan dan pengelolaan data obatnya. Sehingga dibutuhkan suatu sistem yang dapat membantu sistem penjualan dan pengelolaan data obatnya. Agar lebih mempermudah staff dalam membuat laporan data obatnya.Dengan adanya Aplikasi Penjualan dan Persediaan Obat yang diusulkan pada Apotek Merben mampu menghasilkan informasi yang cepat, 
dan tepat waktu sehingga memudahkan dalam pengolahan data penjualan obat dan data stok obatnya. Aplikasi Penjualan dan Persediaan Obat ini berbasis localhost . Dengan adanya Aplikasi ini diharapkan dapat membantu staff ataupun user dalam pengolahan data penjualan, laporan obat keluar, laporan obat masuk, dan laporan cek stok obat[2].

Pada penelitian ketiga oleh Gege Agus Dermawan dari Universitas Pendidikan Ganesha yang berjudul "Penerapan EOQ dalam pengelolaan persediaan bahan baku tepung pada usaha pia ariawan di desa banyuning, dengan bertujuan untuk mengetahui jumlah per pesanan bahan baku tepung Usaha Pia Ariawan dengan menggunakan metode EOQ," dan untuk mengetahui besarnya total biaya persediaan Usaha Pia Ariawan dengan menggunakan metode EOQ. Subjek dalam penelitian ini adalah Usaha Pia Ariawan yang berlokasi di Desa Banyuning Kecamatan Buleleng, dan objeknya adalah pengelolaan persediaan bahan baku tepung. Data dikumpulkan dengan pencatatan dokumen dan wawancara. Data dianalisis dengan metode EOQ. Hasil penelitian ini menunjukan bahwa jumlah per pesanan bahan baku tepung Usaha Pia Ariawan dengan menggunakan metode EOQ sebanyak $878,71 \mathrm{~kg}$, persediaan pengamanan yang harus tersedia sebanyak $26,86 \mathrm{~kg}$, pemesanan kembali seharusnya dilakukan saat persediaan bahan baku tepung sebanyak $91,20 \mathrm{~kg}$, dan persediaan maksimum yang harus ada di gudang adalah 905,57 kg, dan (2) besarnya total biaya persediaan dengan menggunakan metode EOQ sebesar Rp 527.266,71. Jumlah ini lebih kecil bila dibandingkan dengan biaya total persediaan yang harus dikeluarkan oleh perusahaan pada periode yang sama yang mencapai Rp 1.059.102[3].

Penelitian ini merujuk pada beberapa referensi untuk memenuhi kebutuhan teknologi yang akan dipakai pada sistem. Berikut pengertian dan definisi yang menjadi referensi penelitian ini:

Sistem adalah suatu kerangka dari prosedur-prosedur yang saling berhubungan, yang disusun sesuai dengan skema yang menyeluruh untuk melaksanakan suatu kegiatan atau fungsi utama dari perusahaan yang dihasilkan oleh suatu proses tertentu yang bertujuan untuk menyediakan informasi untuk membantu mengambil keputusan[4].

Web application adalah sebuah aplikasi yang diakses menggunakan web browser dan dikembangkan dengan browser-supported languages seperti HTML dan Javascript. Untuk menjalankannya, web application bergantung kepada web browser dan termasuk banyak aplikasi yang sering digunakan seperti aplikasi penjualan online, lelang online dan webmail[5].

Menurut Abidin (2010:7) Kata sistem berasal dari bahasa Latin (systema) dan bahasa Yunani (sustema) yang artinya adalah suatu kesatuan yang terdiri komponen atau elemen yang dihubungkan bersama untuk memudahkan aliran informasi, materi atau energi. Secara umum sistem adalah kumpulan dari beberapa bagian tertentu yang saling berhubungan secara harmonis untuk mencapai suatu tujuan tertentu. Elemen-elemen yang mewakili suatu sistem secara umum adalah masukan (input) pengolahan (processing) dan keluaran (output)[6].

Menurut Kamus Besar Bahasa Indonesia, inventaris yaitu daftar yang memuat semua barang milik kantor yang dipakai dalam melaksanakan tugas. Kegiatan inventaris barang sarpras dilakukan untuk memudahkan pengelolaan. Menurut Gunawan (2011) dalam kegiatan inventaris sarana dan prasarana pendidikan akan dilakukan aktivitas pengurusan, pengaturan dan pencatatan barang sesuai dengan ketentutan yang telah diatur ke dalam buku. Kegiatan inventaris barang sarpras dapat menggunakan sistem informasi[8].

Menurut Yakub (2012)[3] "informasi merupakan data yang telah diproses sedemikian rupa sehingga meningkatkan pengetahuan seseorang yang menggunakannya" [7].

Use Case diagram, merupakan pemodelan untuk kelakukan (behavior) sistem infor-masi yang dibuat. Use case mendeskrip-sikan sebuah interaksi antara satu atau lebih aktor dengan sistem informasi yang akan dibuat[9].

Flow map adalah campuran peta dan flow chart yang menunjukkan pergerakan benda dari satu lokasi ke lokasi lain[10].

Metode EOQ mengasumsikan permintaan secara pasti dengan pemesanan yang dibuat secara konstan serta tidak adanya kekurangan persediaan. Hal-hal yang harus dipenuhi dalam metode EOQ, yaitu Tingkat permintaan diketahui, tidak diperbolehkan terjadinya kehabisan persediaan, 
DOI: $10.52362 /$ jmijayakarta.v1i4.563

bahan yang dipesan dan diproduksi pada satu waktu, biaya pemesanan setiap unit adalah konstan, dan barang yang dipesan tunggal[11].

Susunan data yang digunakan dalam perhitungan EOQ adalah[12]:

a. Kebutuhan rata-rata material

b. Standar Deviasi

c. Rencana kebutuhan material rata-rata selama waktu tenggang

d. Varians selama waktu tenggang

e. Standar Deviasi selama waktu tenggang

f. Persediaan

g. Pemesanan Kembali material

h. Jumlah pemesanan material optimal

i. Frekuensi Pemesanan material

j. Interval waktu pemesanan material

k. Biaya total persediaan

Dalam melakukan penerapan metode penelitian ini metode yang digunakan untuk menganalisa perancangan sistem adalah EOQ (Economy Order Quantity) adalah metode penjumlahan bobot dari kinerja setiap objek-objek yang berbeda dan memiliki kesempatan yang sama pada semua kriteria yang dimiliki. Berikut adalah rumus EOQ (Economy Order Quantity)[13]:

$$
\mathrm{EOQ}=\sqrt{\frac{2 \mathrm{DC}_{\mathrm{O}}}{\mathrm{C}_{\mathrm{u}} \mathrm{i}}}
$$

Keterangan :

D : Total kebutuhan bahan dalam satu tahun

Co : Biaya untuk setiap kali pemesanan

$\mathrm{Cu} \quad$ : Harga per unit

i : Prosentase biaya pemeliharaan

Berdasarkan rumus EOQ tersebut, maka dapat diperoleh rumus frekuensi pemesanan dalam satu tahun adalah sebagai berikut :

$$
F=\frac{\mathrm{D}}{Q}
$$

Keterangan :

$\mathrm{F} \quad$ : Frekuensi pemesanan

D : Total kebutuhan bahan dalam satu tahun

Q : Kuantitas untuk setiap kali pemesanan

Titik Pemesanan Kembali atau Re Order Point merupakan suatu titik dimana harus dilakukannya pemesanan kembali :

$$
\mathrm{ROP}=\left(\frac{E O Q}{\text { Lama perputaran produksi }} x \text { Lead time }\right)+\text { Safety stock }
$$

\section{METODE PENELITIAN (Research Method)}

Pada penelitian ini, peneliti menerapkan tahapan metode penelitian sebagai berikut:

A.Observasi

Observasi dilakukan dengan mengamati secara langsung ke PT. Cakraindo Mitra Internasional tentang permasalahan pada proses Persediaan barang.

B. Wawancara

\section{(i)}


DOI: $10.52362 /$ jmijayakarta.v1i4.563

Wawancara dilakukan dengan bertanya langsung kepada Staf yang ada di PT. Cakraindo Mitra Internasional. Untuk mengetahui apa saja yang menjadi hambatan dan permasalahan pada proses Persediaan barang tersebut dan menanyakan kebutuhan apa saja yang dibutuhkan untuk perancangan sistem informasi sistem pendukung keputusan dalam persediaan barang.

C. Studi Literatur

Studi literatur dilakukan oleh penulis yaitu dengan melakukan pencarian terhadap berbagai sumber tertulis, baik berupa, arsip, majalah, artikel, dan jurnal, atau dokumen-dokumen yang relevan dengan permasalahan yang dikaji. Sehingga informasi yang didapat dari studi kepustakaan ini dijadikan rujukan untuk memperkuat argumentasi-argumentasi yang ada. Selain itu studi literatur juga dilakukan dengan mempelajari data yang didapat dari observasi dan dokumendokumen yang terkait dengan proses penelitian ini. Hal ini dilakukan dengan tujuan untuk mengetahui seperti apa proses sistem yang akan berjalan.

D. Metode Analisis Masalah

Dalam penelitian ini pada PT. Cakraindo Mitra Internasional secara keseluruhan masih bersifat manual dan belum menggunakan sistem yang bisa membantu proses pengambilan keputusan untuk mempermuda melakukan pengecekan persediaan barang. Untuk mengatasi permasalahn tersebut PT. Cakraindo Mitra Internasional membutuhkan aplikasi yang dapat mempermudah melakukan pengecekan persediaan barang.

\section{E. Perancangan Flow Sistem}

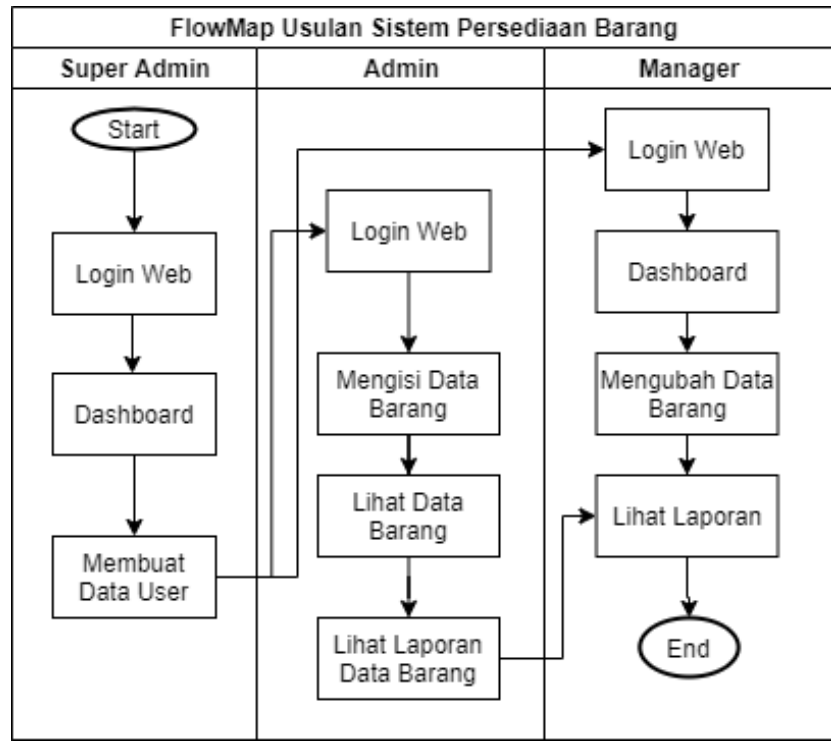

Gambar 1. Flow Diagram Sistem

Pada gambar diatas merupakan flow diagram yang akan diterapkan pada sistem yang terimplementasikan metode EOQ. Dapat diketahui mulai dari login, masing-masing user akan mengakses sesuai dengan role pada sistem dimana super admin dapat membuat user admin dan manager. Lalu admin akan mengisi data barang dan melihat data barang serta dapat membuat laporan data barang untuk manager. Sedangkan user manager akan mengakses data untuk dirubah dan melihat laporan yang telah dikerjakan oleh admin. 


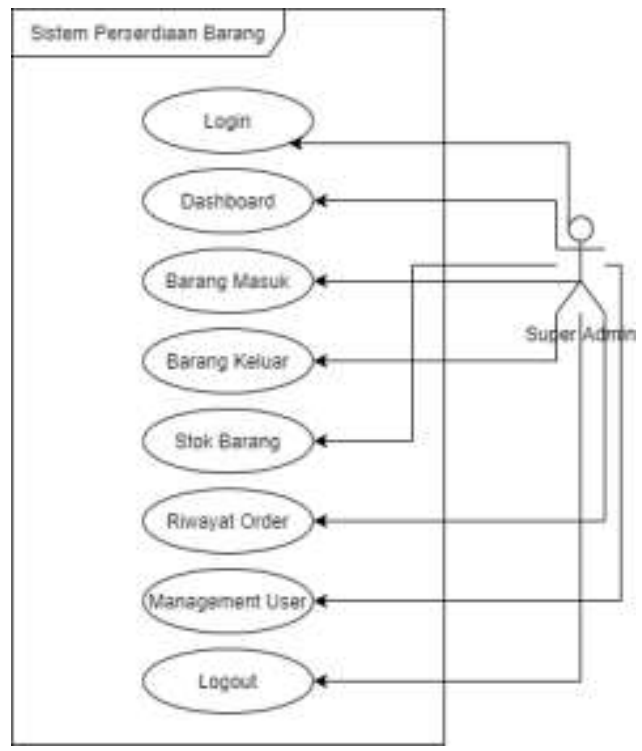

Gambar 2. Usecase Diagram Super Admin

Dapat diketahui bahwa role super admin pada gambar 2 dapat mengakses semua menu pada sistem yang akan mengelola dan emmperbaiki sistem dengan sesuai kebutuhan sistem.

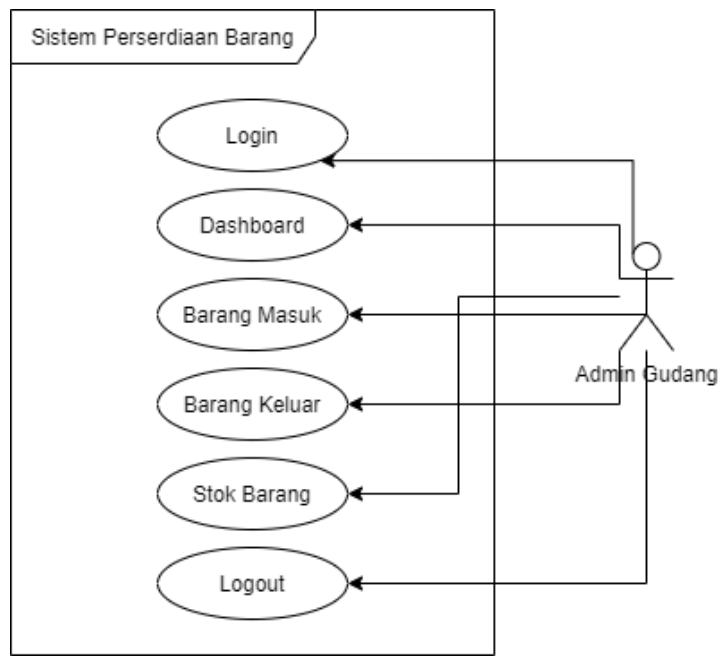

Gambar 3. Usecase Diagram Admin Gudang

Pada gambar 3 dapat diketahui bahwa role admin pada sistem adalah sebagai operator atau pelaksana kerja pada flow diagram sistem ini yang akan dilaporkan pada manager. 
DOI: $10.52362 / j m i j a y a k a r t a . v 1 i 4.563$

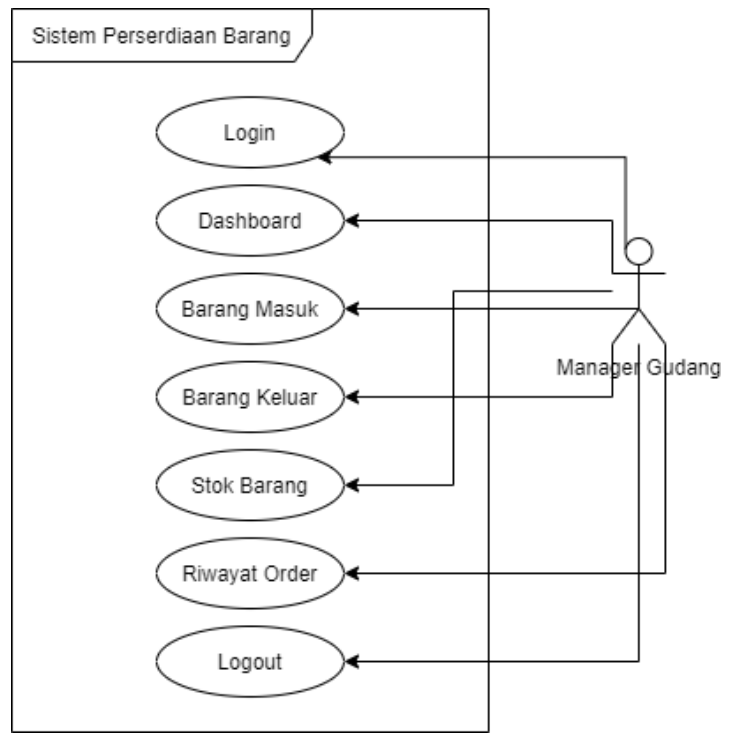

Gambar 4. Usecase Diagram Manager

Pada gambar 4 diatas dapat diketahui user sebagai manager dan dapat mengakses dan mengubah data barang serta menerima laporan dari admin gudang.

\section{F. Pengujian}

Dalam melakukan penelitian ini penulis menjelaskan bagaimana proses rancangan pengujian proses pengendalian persediaan barang PT. Cakraindo Mitra Internasional. Untuk itu dalam upaya perancangan dan implementasi pengendalian persediaan barang diperlukan adanya pengujian sistem berupa penjujian user interface (UI), pengujian fungsi dasar sistem dan pengujian validasi.

I. Pengujian User Interface (UI)

Pengujian User Interface ini bertujuan untuk mengetahui fungsionalitas dari elemen-elemen interface yang terpada pada tiap-tiap halaman bekerja dengan baik. Adapun rencana kasus uji pada pengujian User Interface ini dapat dilihat pada table berikut :

Tabel 1

Rancangan Pengujian

\begin{tabular}{|c|c|c|}
\hline $\begin{array}{c}\text { List of } \\
\text { Function }\end{array}$ & Deskripsi & Keterangan \\
\hline Log In & $\begin{array}{c}\text { Login adalah menu } \\
\text { untuk masuk kedalam } \\
\text { aplikasi system Stock } \\
\text { Opname }\end{array}$ & OK \\
\hline Dashboard & $\begin{array}{c}\text { Dashboard adalah } \\
\text { tampilan menu awal di } \\
\text { dalam aplikasi }\end{array}$ & OK \\
\hline $\begin{array}{c}\text { Data Stock } \\
\text { Barang }\end{array}$ & $\begin{array}{c}\text { Keseluritoring } \\
\text { stok prodak. }\end{array}$ & OK \\
\hline $\begin{array}{c}\text { Data } \\
\text { Barang } \\
\text { Keluar }\end{array}$ & $\begin{array}{c}\text { Monitoring seluruh } \\
\text { data transaksi barang } \\
\text { keluar. }\end{array}$ & OK \\
\hline Logout & $\begin{array}{c}\text { Menu logout } \\
\text { berfungsi untuk keluar } \\
\text { dari akun di system } \\
\text { Stock opname. }\end{array}$ & OK \\
\hline
\end{tabular}




\section{Pengujian Metode EOQ}

Pengujian yang selanjutnya yaitu pengujian metode EOQ yang akan diimplementasi pada program. Dalam melakukan penerapan metode penelitian ini metode yang digunakan untuk menganalisa perancangan sistem adalah EOQ (Economy Order Quantity) adalah metode penjumlahan bobot dari kinerja setiap objek-objek yang berbeda dan memiliki kesempatan yang sama pada semua kriteria yang dimiliki

G. Menarik Kesimpulan

Setelah melakukan pengujian, peneliti dapat menarik kesimpulan hasil dari penelitian ini.

\section{HASIL DAN PEMBAHASAN (Results and Analysis)}

Pembahasan penelitian ini beranjak dari sebuah permasalahan yang ditemui pada PT. Cakraindo Mitra Internasional yaitu dalam divisi gudang dimana pengarsipan masih manual, peneliti melihat permasalahan tersebut mengajukan ide penelitian untuk diterapkan dengan metode EOQ ( Economy Order Quantity) Berdasarkan literature yang suda dibaca dari referensireferensi yang sesuai dengan tema penelitian yang akan dijalani. Setelah mendapatkan literatur yang diperlukan, lalu peneliti dapat menentukan variable yang akan diteliti. Setelah menentukan variable yang akan diteliti, peneliti mengumpulkan data dari PT. Cakraindo Mitra Internasional untuk diolah dan diterapkan dengan metode EOQ ( Economy Order Quantity) yang hasilnya akan diimplementasikn kedalam sistem inventory berbasis web. Berikut hasil hitung data EOQ sample sampai 5 data dari keseluruhan data 20 sample:

Tabel 2. Jumlah Order dalam satu tahun

\begin{tabular}{|c|l|c|}
\hline No. & \multicolumn{1}{|c|}{ Nama Barang } & EOQ \\
\hline 1 & GLYCERIN DOMAS DRUM / DRUM KLK & 13,94 \\
\hline 2 & GLYCERIN KLK & 9,11 \\
\hline 3 & OLEIC ACID MUSIM MAS & 9,82 \\
\hline 4 & HPS (CAKRA9000) & 21,39 \\
\hline 5 & LAURIC ACID ( LA 9812 / 1892 ) KLK & 15,62 \\
\hline
\end{tabular}

Berdasarkan tabel diatas PT. Cakraindo Mitra. harus melakukan jumlah order untuk memenuhi kebutuhannya. Jumlah pemesanan yang dilakukan dalam satu tahun dapat dilihat pada table selanjutnya, jika dalam satu tahun sama dengan 360 hari maka hasil perhitungannya adalah sepeti pada table berikut:

Tabel 3. Jumlah pemesanan yang dilakukan dalam satu tahun

\begin{tabular}{|c|l|c|c|c|}
\hline No. & \multicolumn{1}{|c|}{ Nama Barang } & EOQ & $\begin{array}{c}\text { Jumlah } \\
\text { Order }\end{array}$ & 1 tahun \\
\hline 1 & GLYCERIN DOMAS DRUM / DRUM KLK & 13,94 & 1 & 251 \\
\hline 2 & GLYCERIN KLK & 9,11 & 5 & 80 \\
\hline 3 & OLEIC ACID MUSIM MAS & 9,82 & 2 & 177 \\
\hline 4 & HPS (CAKRA9000) & 21,39 & 10 & 36 \\
\hline 5 & LAURIC ACID ( LA 9812/1892) KLK & 15,62 & 9 & 40 \\
\hline
\end{tabular}

Jumlah diatas adalah untuk mengetahui berapa hari sekali pemesanan yang dilakukan dalam satu tahun.

Hasil dari penelitian ini merupakan implementasi metode pada sistem berbasis web yang akan digunakan pada PT. Cakraindo Mitra. Berikut merupakan layout web yang telah peneliti buat: 
DOI: $10.52362 / j m i j a y a k a r t a . v 1 i 4.563$
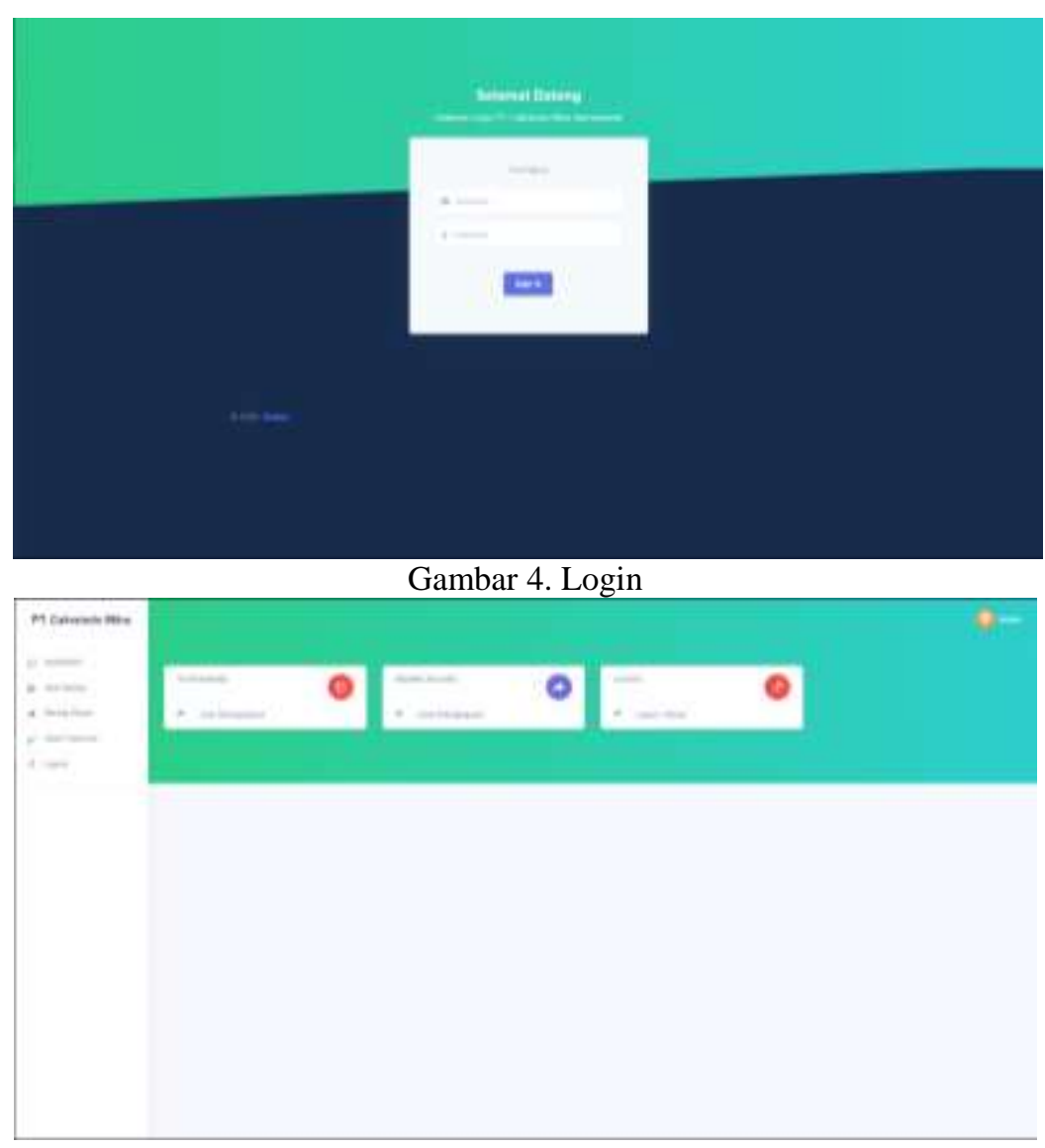

Gambar 5. Dashboard Admin

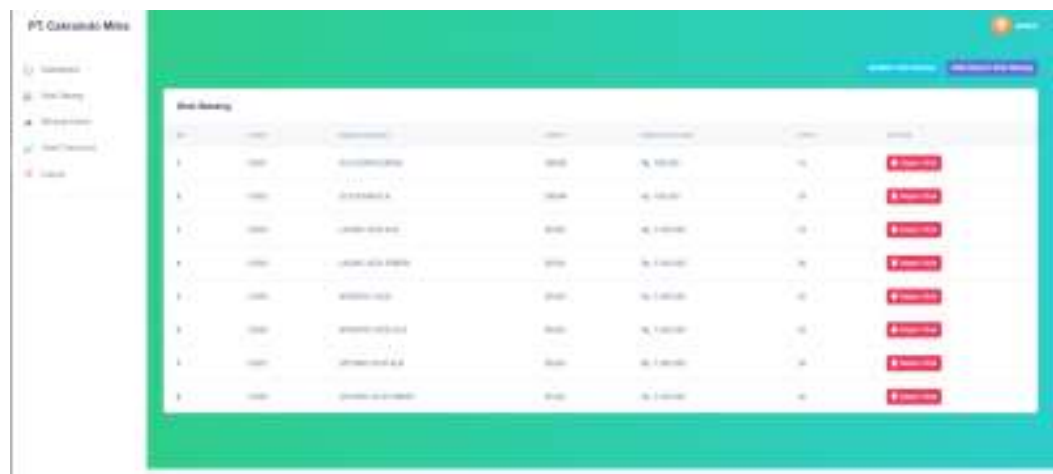

Gambar 6. Stok barang

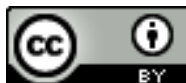

This work is licensed under a Creative Commons Attribution 4.0 International License. http://journal.stmikjayakarta.ac.id/index.php/JMIJayakarta 
DOI: $10.52362 / j m i j a y a k a r t a . v 1 i 4.563$

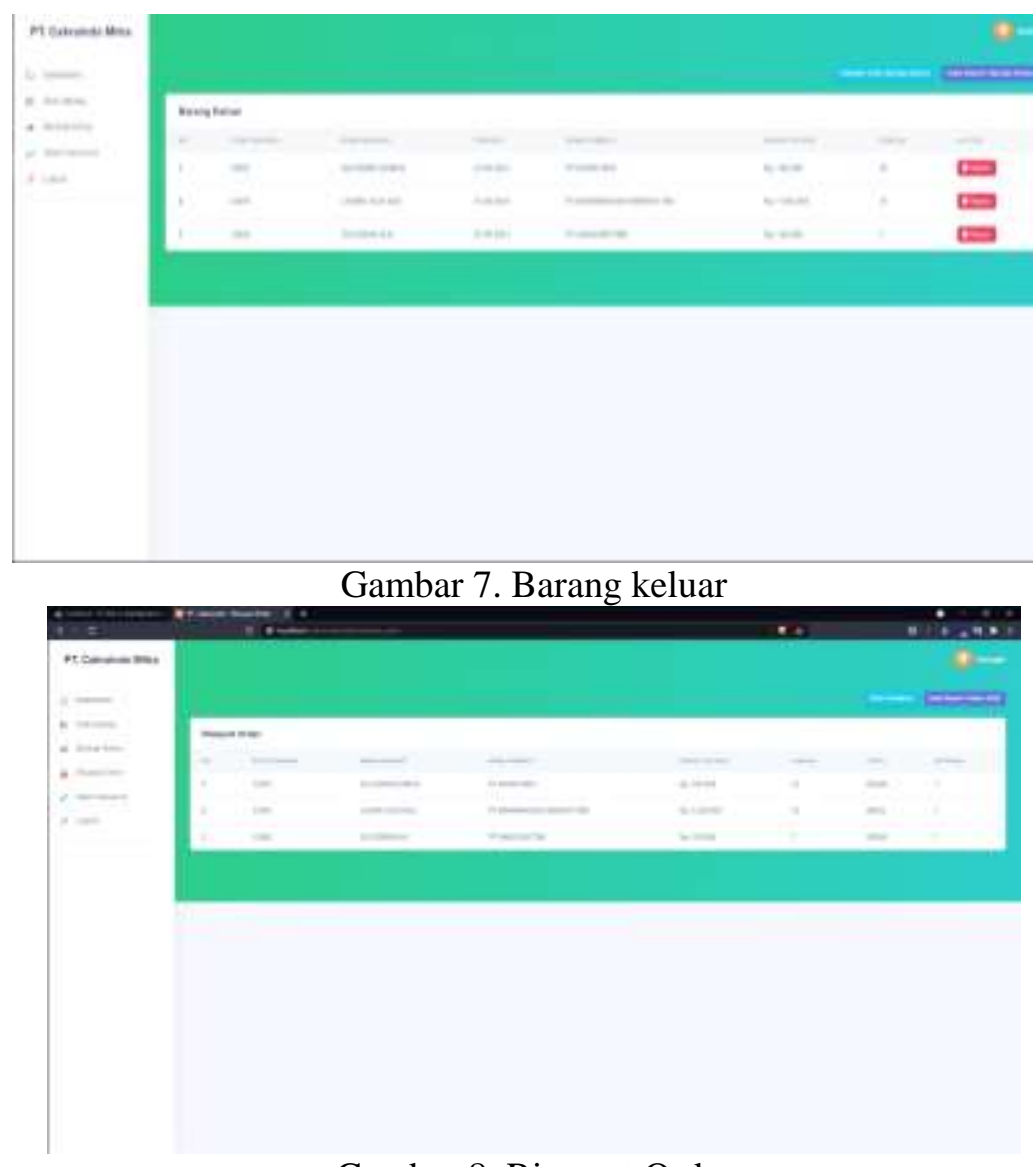

Gambar 8. Riwayat Order

Pada gambar diatas, peneliti menerapkan metode EOQ pada halaman riwayat order yang akan menghitung dengan otomatis interval order dari rransaksi pelanggan tersebut dalam membeli barang tersebut dengan jumlah yang sesuai. Oleh karena itu maka perusahaan terbantu dengan adanya web persediaan barang ini untuk pengendalian barang pada PT. Cakraindo Mitra.

\section{KESIMPULAN (or Conclusion)}

Kesimpulan penelitian ini yaitu sebuah permasalahan yang ditemui pada PT. Cakraindo Mitra Internasional yaitu dalam divisi gudang dimana pengarsipan masih manual, peneliti melihat permasalahan tersebut mengajukan ide penelitian untuk diterapkan dengan metode EOQ ( Economy Order Quantity) Berdasarkan literature yang suda dibaca dari referensi-referensi yang sesuai dengan tema penelitian yang akan dijalani. Setelah mendapatkan literatur yang diperlukan, lalu peneliti dapat menentukan variable yang akan diteliti. Setelah menentukan variable yang akan diteliti, peneliti mengumpulkan data dari PT. Cakraindo Mitra Internasional untuk diolah dan diterapkan dengan metode EOQ ( Economy Order Quantity) yang hasilnya akan diimplementasipak pada pembuatan sistem berbasis web yang akan membantu pengguna untuk mengetahui interval barang yang sering dilakukan transaksi oleh pelanggan dalam setahun terakhir. Dengan telah dibuatnya web tersebut maka pengguna dalam hal ini yaitu PT. Cakraindo Mitra dapat mengetahui pelanggan yang sering bertransaksi dengan perusahaan dan barang yang dipesan selama setiap transaksi berjumlah berapa intervalnya dalam setahun. 


\section{Referensi (Reference)}

[1] A. Amrillah, Z. ZA, and M. NP, "ANALISIS METODE ECONOMIC ORDER QUANTITY (EOQ) SEBAGAI DASAR PENGENDALIAN PERSEDIAAN BAHAN BAKU PEMBANTU (Studi Pada PG. Ngadirejo Kediri - PT. Perkebunan Nusantara X)," J. Adm. Bisnis S1 Univ. Brawijaya, vol. 33, no. 1, pp. 35-42, 2016.

[2] Bambang, "Rancang Bangun Aplikasi Penjualan Dan Persediaan Di Kota Prabumulih," J. Sist. Inf. Dan Komputerisasi Akunt., vol. 1, no. 1, pp. 81-88, 2017, [Online]. Available: http://jsk.ac.id/index.php/JSK/article/view/11.

[3] M. S.E., "Penerapan Economic Order Quantity (Eoq) Dalam Pengelolaan Persediaan Bahan Baku Tepung Pada Usaha Pia Ariawan Di Desa Banyuning Tahun 2013," J. Manaj. Indones., vol. 3, no. 1, 2015.

[4] i gusti ngurah anom Cahyadi Putra and agus tommy prawira Kusuma, "Informasi Pengaduan Inventaris Kelas," J. Teknol. Dan Komput., vol. 5, pp. 35-39, 2019.

[5] A. P. Kuncoro and A. Purnomo, "SATIN - Sains dan Teknologi In form asi Pengembangan Sistem Informasi Berbasis Website $\mathrm{s}$ ebagai Media Pengelolaan Peminjaman dan Pengembalian Alat," vol. 4, no. 2, 2018.

[6] P. Sutopo, D. Cahyadi, and Z. Arifin, "Sistem Informasi Eksekutif Sebaran Penjualan Kendaraan Bermotor Roda 2 di Kalimantan Timur Berbasis Web," Inform. Mulawarman J. Ilm. Ilmu Komput., vol. 11, no. 1, p. 23, 2016, doi: 10.30872/jim.v11i1.199.

[7] N. S. Syahrul Mauluddin, "Sistem Informasi Persediaan Dan Penjualan Barang Berbasis Desktop Di D-Net House," Pros. Semin. Nas. Tek. Komput. dan Rekayasa, no. October, pp. III-12, 2018.

[8] P. Dharma, S. Handoyo, S. A. Wicaksono, and Y. T. Mursityo, "Pengembangan Sistem Informasi Manajemen Inventaris Barang ( Studi pada SMAN 2 Malang )," J. Pengemb. Teknol. Inf. dan Ilmu Komput., vol. 3, no. 10, pp. 9717-9726, 2019.

[9] E. Affandi and T. Syahputra, "Pemodelan Uml Manajeman Sistem Inventory," J. Teknol. Sist. Inf. dan Sist. Komput. TGD, vol. 1, no. 2, pp. 14-25, 2018.

[10] H. Bagir and B. E. Putro, "Analisis Perancangan Sistem Informasi Pergudangan di CV. Karya Nugraha," J. Media Tek. dan Sist. Ind., vol. 2, no. 1, p. 30, 2018, doi: 10.35194/jmtsi.v2i1.274.

[11] A. Candra, "Pengendalian Persediaan Material Pada Produksi Hot Mix Dengan Pendekatan Metode Economic Order Quantity (EOQ)," Jitmi, vol. 1, pp. 145-153, 2018.

[12] R. Careza, Y. Sudarso, and S. E. Sadriatwati, "Analisis Perbandingan Metode EOQ dan Metode POQ dengan Metode Min-Max dalam Pengendalian Persediaan Bahan Baku pada PT Sidomuncul Pupuk Nusantara," Admisi dan Bisnis, vol. 17, no. 1, pp. 11-22, 2017.

[13] N. Apriyani and A. Muhsin, "Analisis Pengendalian Persediaan Bahan Baku Dengan Metode Economic Order Quantity Dan Kanban Pada Pt Adyawinsa Stamping Industries," Opsi, vol. 10, no. 2, p. 128, 2017, doi: 10.31315/opsi.v10i2.2108. 